\section{A CASE OF PNEUMONIA.}

By T. CAMEron, M.B., C.M. GLAsG.

I was lately called in to see a young man, J. W-, aged eighteen, and found him suffering from the following symptoms:--Ie complained of an irritating cough, with slight expectoration of blood-tinged sputum. On examination dulness was found over the whole lower lobe of the right lung, with tubular breathing and crepitant râles. Temperature $104 \cdot 4^{\circ}$; pulse 120 ; respiration 30 . In fact, he was suffering from all the well-known symptoms of pneumonia. The following day he was seen in consultation with my friend, Dr. (xray, who confirmed my diagnosis. The patient's temperature was then $103^{\circ}$, and his pulse 110 . From that date his temperature, pulse, and respiration went down rapidly to the normal, so that on the sixth day from my first visit he was practically well, except for a few bronchial rîles and some general weakness. My object in writing this short account of the case is to point out a factor in the process of resolution hitherto neglected. The amount of sputum during the whole illness did not exceed an ounce. As the case was an undoubted one of complete consolidation of the whole lower lobe, absorption of the exuded material by the lymphaties and bloodvessels of the lung is the only explanation of the rapid recovery which took place. It has occurred to me that in this theory we have a rational explanation of the good supposed to be done by the old treatment of depletion, an empty condition of the vessels naturally favouring absorption. The treatment in this case was of the ordinary character-an expectorant mixture, and 5 -grain doses of quinine to reduce the temperature. I think that in obstinate cases where resolution is delayed, a more active treatment by the absorbent class of drugs might be more beneficial than the usual continuation of expectorant and tonic medicines. Hull.

MULTIPLE NASAL POLYPI. By Percy G. Lewis, M.D.

A montil ago, Mrs. L- aged fifty-four, came to me with the following history. For ten years she had suffered from more or less nasal obstruction, and for six of those years she had not been able to breathe through her nose at all. She had about eight years ago consulted several doctors, some of whom removed a polypus or two, with forceps, in the usual way. She, however, experienced no relief, and the pain of the operation was so great that she had refrained from seeking advice since. Latterly, however, she had been able to see "something growing in her nose," which caused her uneasiness. On examination both nostrils were found completely blocked with a number of mucous polypi, and the finger passed up behind the soft palate detected a number of grape-like masses there. Having painted the nostrils with cocaine I removed, practically without pain, fifty-one polypi in all, with a Hilton's snare, the operation requiring six separate sittings. Practically there was no bleeding. The snaring of those which projected behind the soft palate was greatly facilitated by passing the finger behind it and pushing them forward. By using a Thudichun's speculum, forehead reflector, and gaslight, a very good illumination was obtained. The polypi varied in size from $\frac{1}{3}$ in. to $\frac{3}{4}$ in., three being over an inch in diameter. After the last sitting the patient could breathe freely through each nostril.

Folkestone.

\section{EPIDEMIC PNEUMONIA.}

BY A. BRENCHLEY, M.D.

IN May and June, 1889, in South London, I had several cases of pneumonia-about twelve in all. Coming close together as regards time-four, also, being in one familyforced the conclusion on me that they must be epidemic. The symptoms were those usual to pneumonia. Fever, basic lung inflammation, dulness, crepitation (generally spreading to the opposite side), a good deal of pain from pleuritic complication, spitting of blood, and a thick glairy, tenacious mucus of a rusty colour adhering to utensils, dyspnœe, \&c. Though of various ages, and some being in extreme danger at the time, they all eventually got well. To account for the cause of these cases at the time gave me a good deal of thought; but, after the experience of the winter epidemic of influenza, I have thought that they might have been probably in some way connected with that - a sort of mild epidemic as a forerunner of the more severe (in point of numbers). From my experience there is no doubt pneumonia is at times contagious or communicable, and I knew an instance where the facts strongly supported the idea that a medical man caught it while attending a case, and died, though there is great difficulty in proving such things.

Denmark-hill, S.E.

\section{dy athror}

\section{HOSPITAL PRACTICE, BRITISH AND FOREIGN.}

Nulla autem est alia pro certo noscendi via, nisi quamplurimas et mot borum et dissectionum historias, tum aliorum tum proprias collectas habere, et inter se comparare.-MoRgaGNI De Sed. et Caus. Morb., lib. iv. Procemium.

\section{BELGRAVE HOSPITAL FOR CHILDREN.}

A CASE OF OPERATION FOR DEVIATED SEPTUM; REMARKS.

(Under the care of Mr. Clinton Dent.)

THE symptoms produced by the condition of deviation of the septum of the nose which is illustrated by this case frequently cause considerable discomfort to the patient the subject of the deformity. Beyond the obstruction to the nostril, and other symptoms complained of by this patient, there may be chronic nasal catarrh, frontal headache, giddiness, and, if the deformity is acquired, an al tered tone of the voice. Rosenthal, ${ }^{1}$ after many examinations, found the deviations most frequent on the left side; the majority of these were situated in the anterior three-fourths of the cavity, therefore implicating chiefly the cartilage. Von Volkmann, ${ }^{2}$ who formerly considered all deflections of the septum as due to injury, states that he now considers the majority dependent upon arrest of development. Dr. Robertson ${ }^{3}$ of Detroit, who examined 227 cases, found eighty-three clear cases of injury, whilst of the remainder, half are said to have presented evidence of fracture or of dislocation. Dr. Delavan, ${ }^{4}$ from a study of the subject, infers that the septum is one of the last parts of the nose to assume its ultimate form. The delay in the general development of the nose is followed at a later period by a sudden activity of growth, involving consequent inequality of development; this occurring probably not before the age of seven years. The septum, of irregular construction, usseous and strong in its posterior aspect and weak in its anterior, surrounded by unyielding walls, bends in the direction of least resistance as growth proceeds, and the various parts being pushed aside from their various planes, a socalled congenital deflection follows. ${ }^{3}$ It is stated that race is a strong predisposing cause (in the European 50 per cent. present more or less marked deviation, the Slavonic and Hebrew races furnishing the highest proportion); that among primitive types deformities are rare, while in the highly civilised they are almost the rule, catarrhal conditions due to surroundings being an important factor. For the following notes we are indebted to Miss F. M. Dickinson, house surgeon.

William $\mathrm{G}-$, aged seven, was admitted to the hospital on Jan. 29th, 1890. His nose was markedly curved, the bony septum deviating to the left to a distance of nearly three-eighths of an inch from the vertical, the nasal cartilage below this point curving back towards the middle line. On looking into the left nostril the passage was seen to be obstructed by a red mucous membrane covered body just within the anterior nares, not unlike a polypus in appearance. 